\title{
Terminology of the Penal Code Procedure - Options of Translation in Albanian and German \\ Dr. Ergys Prifti
}

\author{
Dr. Mihallaq Zilexhiu
}

University of Tirana, Abteilung für deutsche Sprache

ergysp@yahoo.de

\section{Doi:10.5901/ajis.2015.v4n1s1p69}

\section{Abstract}

The Justice, be it civil or penal should be forwarded through a particular form of language. This linguistic form can be orally and in written form as in the case of different linguistic processes, as well as in only written form as in the case of translation of laws or legal provisions. Discussion on legal right and right's judgment, are processes transmitted with the help of language, which are based on texts such as decisions based on language. Language content of these texts is crucial. An equally important role is taken therefore by oral interpreters and those who translate written texts from one language to another. Translators (interpreters) forward the language content in linguistic processes between the defendant in the trial and the plaintiff. But how is it possible to correctly translate the content of a text in written or oral form? What can the translator do in cases of uncertainty? In order to give a possible answer to these questions, the following paper will try to address the following issues: - Brief historical overview of the Albanian code of penal procedure: In this way we can better understand the present status of the penal code procedure in our country, whose history becomes quite often the cause of the problems for the translator. The first Albanian penal code was written in 1925. It was conceived based on the Italian penal code procedures at that time. It was approved in 1927 and in 1928 entered into force. In 1948, was written a part of penal code which was totally completed in 1952. In 1977 was compiled a new Albanian Constitution. After the fall of the communist regime, in 1993 we have some minor amendments of the Constitution, while in 1995 comes out the new penal code procedure under the guidance of specialists in the field from Western countries.

Keywords: Terminology, Penal Code Procedure. Options of Translation, Albanian, German

\section{Introduction}

The new Constitution of Republic of Albania is written in 1998. Let us consider now some typical examples that constitute a kind of difficulty, but also a challenge for the translator of materials linked to the penal code procedure in the Republic of Albania and Republic of Germany. Here follows a translation model known worldwide:

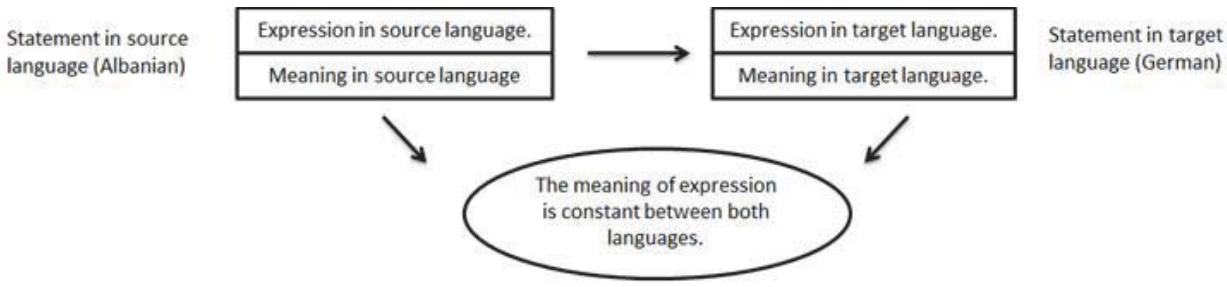

Expressions in the source language. By this we understand the form of the language form which we are translating and the meaning from this language. We then have the form of target language and its meaning. Finally we come to the expression of the target language. The meaning of the expression is constant between both languages.

Different types of word belonging:

I. one to zero

II. one to many

III. many to one 


\section{One to Zero}

- German. Prokurist

- Rechtspfleger

- $\quad$ Sicherungsverwahrung

- Bagatelldelikt

- All above words have not an equivalent in Albanian. In these cases it is left to the translator to realise the translation, which arises the risk of having more than one translation version. Here follow some examples of such translations:

German - Schiedsgutachtensordnung

Albanian - Rregullore ndërmjetësimi

English - Arbitration Regulation

German - Mediationsordnung

Albanian - Rregullore ndërmjetësimi

English - Mediation Regulation

German - Konfliktmenagementordnung

Shqip - Rregullore për menaxhimin e konflikteve

English - Rules on Conflict Management

German - Verfahrensrordnung für Adjudikation

Shqip - Rregullore për adjudikacionin

English - Regulation on adjudication

In such a case, the interpreter is in front of three different translation options:

1. He can take the phrase and translate it in form of a quote or as a loan:

German - Ombudsman / ombucman (Shqip. Avokat i popullit?)

2. The interpreter can give a literal translation of the borrowed word:

German - Bundeskartellamt

Shqip - Autoriteti federal i konkurrencës

English - The Federal Competition Authority

German - Einbruchsdiebstahl

Shqip - Vjedhje me dhunë (thyerje)

English - Robbery use of violence (breaking)

German - Bundesgerichtshof

Shqip - Gjykata Federale (e Lartë) gjermane

English - Federal German (High) Court

3. The translator uses a word from the target language which stands closer to the meaning of the word which is being translated:

German - Prokurist

Shqip - Përfaqësues tregëtar

English - Trade representative

German - Rechtspfleger

Shqip - Ndihmës (këshilltar) ligjor

English - Legal assistant (advisor)

German - Bagatellendelikt

Shqip - vepër e lehtë penale

English - a light penal offence

\section{One Word with Many Words}

German - Vorsätzliche Tötung

1. Shqip - Vrasje me paramendim / English - Premeditated Murder

2. Shqip - Vrasje me dashje /English - Intentional Murder

German - Vorsätzliche Körperverletzung -

1. Shqip - plagosje me paramendim /English - Premeditated injury 


\section{Shqip - plagosje me dashje /English - Intentional injury}

\section{Many Words with a Word}

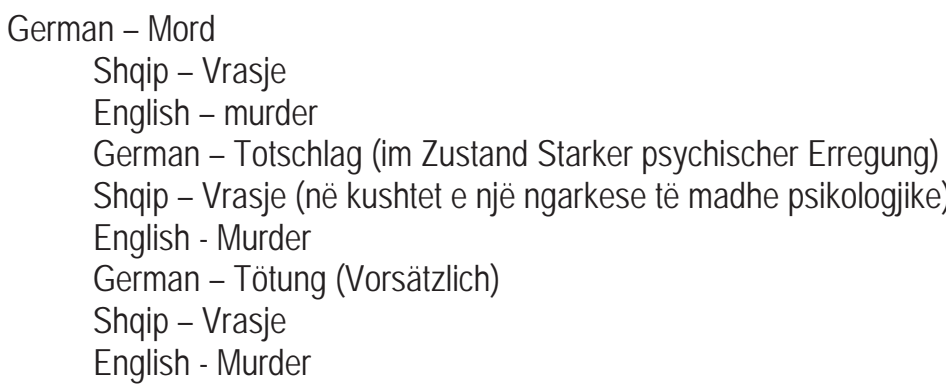

In fact, the word murder for different situations has different words in German:

- of man - Either Mord, and Totschlag are intentional killing of other people but the word murder expressed by the word Mord, is punished more severely than that expressed by the word Totschlag.

In the German penal procedure code, Totschlag means premeditated murder of a man, which did not fulfill either the criteria to be punished as a Mord, nor even those of mitigation to be considered as a Tötung.

Murder by negligence (die fahrlässige Tötung) is considered as an offense of murder in the narrower sense.

Art. 76 Sh - Vrasje me dashje

E - Intentional murder (killing simple)

Gj - Vorsätzliche Tötung

Art. $78 \mathrm{Sh}$ - Vrasja me paramendim

E - Premeditated murder

Gj - Tötung mit Vorbedacht

Art. 79 Sh - Vrasja në rrethana cilësuese

$\mathrm{E}$ - Murder in qualifying circumstances

Gj - Tötung unter qualifizierten Umständen

Art. 81 Sh. Vrasje e Foshnjës

E - Infanticide

Gj - Kindestötung

Art 82 Sh - Vrasja e kryer në kushtet e tronditjes së fortë psiqike

$\mathrm{E}$ - Murder under profound psychic troubles

Gj - Totschlag im Zustand starker psychischer Erregung

Art Sh - Vrasje e kryer me kapërcim të kufijve të mbrojjes së nevojshme

$\mathrm{E}$ - Murder committed by overcoming the limits of necessary defense

Gj - Totschlag bei Notwehrexzess

\section{Many Words with a Word:}

G - Angeschuldigter /Sh. (person i akuzuar) / E - (defendant?)

G - Angeklagter / Sh - Person i akuzuar. / E - Charged person

G - Beschuldigter / Sh - Person nën hetim / E - Person under investigation

Common to all three translations most commonly encountered in our dictionary of penal code procedures is (person i akuzuar) the accused person.

Let's look now one by one which are the meaning and their differences for the above mentioned words used in German.

Angeschuldigter, under the German law, is someone who is convicted in a penal proceeding, against whom is sued a public accusation, but the main proceedings against him is not yet opened.

Beschuldigter in the German penal code procedure is an adult person against whom are charges of a criminal offense and due to that a criminal investigation process is under development against him.

Angeklagter under the German Penal Code Procedure is the defendant against whom it is set to open the main investigation process under Article 203 of Penal Code Procedure (Article 157 StPO). 


\section{Example 4}

Many words with a word:

G - (Gerichts) Verhandlung / Sh - séancë gjyqësore / E - hearing session

G - Sitzung des Gerichtshofs / Sh - séancë gjyqësore / E - hearing session

Example 5

Many question with a word:

G - Diebstahl / Sh - Vjedhje / E - theft

$\mathrm{G}$ - Einbruchsdiebstahl / Sh - vjedhje me dhunë / E - Robbery with violence (breaking)

G - Raub / Sh - Vjedhje me dhunë / E - Violent Robbery

Here follows an illustrative example from a newspaper:

\section{Car Theft ( E.P M. Z) - How to Reduce the Risk}

Monday, January 31, 2011

Theft of parts - For many years, radio theft has been the biggest problem, but recently thiefs have become more ambitious. Now they steal the steering wheel, airbags and electronic control modules (ECT). ECT are computers which control electronic systems of today's cars. They are small parts, of great value, easy to find and very easy to steal. Sound systems remain as well desirable targets for theft.

\section{Conclusions}

At the end of this analysis paper we can say that the problem identification in the field of translation in jurisprudence requires a great work and is very important. All the above mentioned cases can be prevented if they are well known and translations of many words either in Albanian or in German can be given by the equivalent in the relevant language and in many cases their meaning should be completed by explanatory words if the word itself in target language is not sufficient to translate as simply equivalent. On the other hand we share the opinion that necessary work and efforts should be made for a possible unification of terminology in the field of jurisprudence vocabulary and in preparation of a guidance material for all translators dealing with materials in field of justice in their daily activity.

\section{References}

Albanisches Strafgesetzbuch (Sammlung Ausserdeutscher Strafge.) Amazon. De German Edition 1977

Die im Vergleich mit albanischen Strafrechtsreeformen Rechtsakten EU. Endri Papajorgji 2010 Publisher: VDM Verlag Dr. Mutter

Code of Criminal Procedure of the Republic of Albania (I updated to October 2004) 